DOI https://doi.org/10.30525/978-9934-588-80-8-2.62

\title{
HEALTH PRESERVING LEARNING ENVIRONMENT AS A MODERN TREND OF UKRAINIAN HIGHER EDUCATION
}

\author{
Kurlishchuk I. I. \\ Candidate of Pedagogical Sciences, \\ Senior Lecturer at the Pedagogical Department \\ Luhansk Taras Shevchenko National University \\ Aleksieieva O. R. \\ Candidate of Pedagogical Sciences, \\ Senior Lecturer at the Pedagogical Department \\ Luhansk Taras Shevchenko National University \\ Shvyrka V. M. \\ Candidate of Pedagogical Sciences, Associate Professor, \\ Head of Pedagogical Department \\ Luhansk Taras Shevchenko National University \\ Starobilsk, Luhansk Oblast, Ukraine
}

In Ukraine the problem of formation health preserving learning environment at higher education institutions is obvious nowadays due to COVID-19. In the light of the coronavirus outbreak, physical, mental, social health of all participants of the educational process is the primary task. Modern Ukrainian system of higher education provides strategies and implements systematic companies that support necessary conditions for health preserving educational environment formation as well as popularizes the values of human health and healthy lifestyle. Safeguarding and promoting the welfare of all participants of the educational process of higher establishment is defined for such purposes as preventing impairment of educators and university students' mental and physical health or development, protecting from maltreatment, provide with safe and effective conditions of work and study and others. To our mind, it is helped to develop personal and social potential of both educator and learner and to create new opportunities that pursue better life conditions for the whole Ukrainian society.

In any society, the youth is an important age group. It is expected that this social group will advance the economic, social, cultural processes in the country. Ukraine is not an exception. In our country, the role of the youth is not just important as active participants of modern community life, but also 
as the audience for promoting values of democratic civic society, such as freedom of speech, inclusiveness and equality, tolerance and so on.

So, today the problem of youth health, particularly university student youth, is a priority one. Preservation and improvement of university student health is presumed to be an issue of vital national interest and a common task of society, communities, higher educational institutions, as the health of students is the main condition for their further social value, and therefore a guarantee of the prospects for successful development of the strong civil society. Among the key areas of Ukrainian state educational policy identified by the National Doctrine for the Development of Education for the period up to 2021, is the formation of health preserving learning environment that include optimizing academic and social, mental and physical loads and the creation proper conditions for preserving and strengthening health of students in educational institutions.

A number of foreign and domestic scholars (Diachenko-Bohun M., 2016; Gryniova M. et al., 2019; Kovalenko O. et al., 2017; Mityayeva A., 2012; Momot O., 2018; Pyastolova N., 2019, etc.) focuses on the fact that individual health is determined by the environment in which one lives; and for university youth this environment is the educational establishment. It declared that a student aged $18-25,70 \%$ of his/her time is associated with staying in educational institution.

Thus, university students' perceptions of their current learning environment is «a strong predictor of learning outcomes at university» [3, p.49]. And health-preserving learning environment can refer not only to physical settings in which teaching and learning occur but to psychological, social, cultural approaches as well. It is a platform for engaging new personal, social and professional skills.

In modern theory and practice, a considerable number of researches on the issues of learning environment have been conducted (Antonova O. \& Polishchuk N., 2016, Baum E., 2018, Berezhna T. \& Karpenko N. 2017, Lavrentieva O. et al., 2019, Meshko H., 2017, Onipko V., 2019, Pysmennyi O. \& Melnyk O., 2019, Slyvka L., 2015, Yefimova V., 2010 and others), particularly university health preserving learning environment (DiachenkoBohun, M. et al., 2019, Fullerton D.S., 2011, Gonzalez- Zamar M-D. et al., 2020, Harkusha V. \& Aryshchenko V., 2014, Kohli W., 2018, Malysheva L., 2018, Rybalko L., 2018, Svyrydiuk O., 2014, Vitiuk V., 2018, and others).

Nevertheless, a number of modern aspects of health preserving environment of education institutions, in particular learning environment of higher educational establishments required further study. 
The aim of the article is to describe the modern features and to analyze the impact of health preserving learning environment on university students' educational outcomes and physical, mental, social wellness.

Theoretical framework of the research encompassed modern conceptions of pedagogy and methodology and the following methods were used: 1) general scientific (analysis, synthesis, abstraction, comparison and synthesis) and 2) specific scientific (logical analysis, structural and functional analysis, generalization and interpretation of results).

Studying the problem requires the main terms of the research should be analyzed.

Analyzing the issues of the term «learning environment of higher education institution», the researchers Maria Bratko [1], Peter J. Smith \& Damian Blake [4] and Elvira Zaredinova [5] note that learning environments have both a direct and indirect influence on university student learning, their motivation to learn, and their sense of well-being and personal or social safety. The structure of learning environment of modern higher education institution includes several elements such as the physical environment refers to the buildings, furniture and equipment that also covers the technical learning environment; the pedagogical environment covers the pedagogical methods and practices used in learning and teaching; the psychological environment covers the cognitive environment and the emotional environment as well; the social environment; the health -saving environment.

Nowadays due to the coronavirus outbreak, the health preserving aspect of learning environment of higher education is a vital one. It is explained as a basic tool for organization of active cognitive activity of university students is carried out in order to master the system of professional competencies envisaged in the educational programs for the training of future specialists.

Maryna Diachenko-Bohun et al. emphasize that «health preserving educational environment enables: 1) purposeful system of conditions for scholarly activity, which not only does any harm to the health, but also ensures its formation, preservation and strengthening in all participants of the educational process; 2) application of active forms and methods of education aimed at creating a comfortable health-saving psychological atmosphere during classes; 3 ) awareness of teachers and students about ways to preserve health and respect for their health preserving behavior; 4) developing in students, in future specialists of value attitudes towards their health and the health of their peers» [2, p.95].

In our opinion, health preserving learning environment of modern higher educational institutions works to build safe learning spaces for each student 
and educator. It tries to be nimble and adjust as the needs of all participants of educational process shift. At the same time, health preserving learning environment recognizes that university student success is a complex idea and measuring it must be accomplished with many tools and it is should led by people who value others' interests and needs. Special attention should be paid to subjective and objective factors contributing to the preservation of health as well as to the development of readiness for the realization of health preserving technologies in professional activity and self-education in the direction of formation and maintenance of health.

Conclusion. So, we define the term «health preserving learning environment of higher educational institution» as a complex of all physical surroundings, psychological and emotional conditions, and social or cultural influences affecting the development of a university student. The work on effective health preserving learning environment creation should aim to improve efficiently support the pedagogies and organization forms necessary to develop students' capacities for the 21 st century. It is obvious that learning environments cannot simply be planned and implemented in some mechanistic ways, they need to be sites of attentive nurturing, strong flexibility and great adaptability.

\section{References:}

1. Bratko M. (2015). Education environment of higher education institution: the functional aspect. The pedagogical process: theory and practice.№ 1-2 (46-47). Pp. 11-16 [in Ukrainian]

2. Diachenko-Bohun, M., Rybalko, L., Grygus, I. \& Zukow, W. (2019). Health Preserving Educational Environment in the Condition for Information Technologies. Journal of History Culture and Art Research, 8(2), 93-101. DOI:http://dx.doi.org/10.7596/taksad.v8i2.2075

3. Lizzio A., Wilson K. \& Simons R. (2002). University Students' Perceptions of the Learning Environment and Academic Outcomes: Implications for theory and practice. Studies in Higher Education. Volume 27. Issue 1. Pp. 27-52. DOI: https://doi.org/10.1080/03075070120099359

4. Smith J. Peter \& Blake D. (2009). The influence of learning environment on student conceptions of learning. Journal of Vocational Education \& Training. Volume 61. Issue 3. Pp. 231-246 DOI: https://doi.org/10.1080/13636820902996517

5. Zaretinova E. (2017). The Definitional Analysis of the Concept «The Educational Environment of Universities». Bulletin of Luhansk Taras Shevchenko National University.Pedagogical Sciences. № 8(1). Pp. 193-200 [in Ukrainian] 